UDC 621.793.6

DOI 10.36910/6775-2313-5352-2020-17-17

B.P. Sereda, Ph.D., professor, I.V. Kruglyak, Ph.D., associate professor

Dnipro State Technical University

\title{
SURFACE HARDENING OF CONSTRUCTION MATERIALS WITH THE USE OF COMPOSITE SATURATING CHARGES
}

\begin{abstract}
The article discusses the formation of the structure of protective diffusion layers using composite saturating charges on structural materials with different carbon content. A thermodynamic analysis of the gas phase at saturation has been carried out. The composition of the gas phase has been determined. Gaseous products interact with elements of the powder system (Al, Mo, Cr) and are transformed into the gas phase ( $\mathrm{CrH}, \mathrm{CrOH}, \mathrm{CrCl}, \mathrm{CrCl}_{2}, \mathrm{CrCl}_{3}$, $\mathrm{CrOH}, \mathrm{CrOCl}_{2}, \mathrm{CrI}, \mathrm{CrI}_{2}, \mathrm{CrI}_{3}, \mathrm{MoCl}, \mathrm{MoCl}, \mathrm{MoCl}_{3}, \mathrm{MoCl}_{4}, \mathrm{MoOCl}, \mathrm{MoOCl}_{2}, \mathrm{MoI}, \mathrm{MoI}_{2}, \mathrm{MoI}_{3}$, $\mathrm{MoI}_{4}$ ). Using $3 \mathrm{D}$ modeling of microstructures, it was possible to more fully establish the nature of the distribution of phases and inclusions in the diffusion layer. The relationship between the $3 D$ microstructure of the material and its physical and mechanical properties made it possible to carry out modeling to obtain the optimal composition of the developed composite charge for saturation. Diffuse layers are formed on the surface of structural materials, which contain Mo2C and $\alpha$ phases - the $\mathrm{Cr}, \mathrm{Al}$, Mo phase, the inclusion of $\mathrm{Fe}_{7} \mathrm{Mo}_{6},(\mathrm{Fe}, \mathrm{Cr}, \mathrm{Al}, \mathrm{Mo})_{23} \mathrm{C}_{6}$. Carbides of three types were found: hexagonal chromium carbide $\mathrm{Cr}_{7} \mathrm{C}_{3}$ and carbides $\mathrm{Mo}_{2} \mathrm{C}, \mathrm{Cr}_{23} \mathrm{C}, \mathrm{Fe}_{3} \mathrm{Mo}_{3} \mathrm{C}$ $u \mathrm{Fe}_{2} \mathrm{Mo}_{2} \mathrm{C}$. The physical, mechanical and operational properties of structural materials with protective diffusion coatings have been investigated. At tests in the conditions of sliding friction the best wear resistance among the considered diffusion coverings has vanadium, titanium and borized. Their wear resistance is 1.8 - 2.3 times greater than that of coatings obtained under isothermal conditions.
\end{abstract}

Keywords: diffusion, molybdenum, modeling, microstructure, phase, microhardness, residual stresses, wear resistance.

Introduction and statement of the problem. The modern development of mechanical engineering is closely related to the widespread use of new structural materials. The performance properties of parts can be enhanced by modifying the surface layers. One of the ways to achieve the modification of the structure and phase composition of parts operating under conditions of metallurgical production is saturation of the surface with metals during chemical-thermal treatment. Chemical heat treatment is an effective method of affecting the working surfaces of machine parts. After it is carried out, high-quality diffuse layers are obtained on the operating surfaces, which then turn into the base material, which is positive in terms of strength and stability. In this case, the treatment provides the formation of layers with a carbide structure based on chromium, molybdenum, vanadium, titanium.

Analysis of recent publications. The idea of creating a diffusion zone with a specific chemical composition on their surface attracts the attention of specialists primarily due to its rationality. It is on the surface of products that cracks originate - precursors of destruction, maximum stress arises as a reaction to operational loads, phenomena of intense wear are observed during friction against the product, they are combined [1-4].

The authors of [1] proposed a chemical-thermal treatment (CTT) scheme that does not provide for hermetic sealing of the container, its evacuation or filling with argon, as well as the excitation of mechanical vibrations of the container and the product. In addition, a saturating medium is used, it experiences an exothermic reaction when heated and ignited. As such a medium, coal powder was chosen, it plays the role of a source of atomic carbon, a micro-arcing medium and has a significant thermal effect during combustion.

To strengthen the working surfaces of parts of friction pairs, a new complex method of hardening the surfaces of machine parts has been developed [6], which consists of chemical deposition and diffusion Cr-Ti. A composite structure of a reinforced layer of significant thickness and rigidity is formed, provides high wear resistance of parts, strengthened by this method.

For high-wear parts of machines, a combination of two or more methods of chemical heat treatment is promising as methods of chemical-thermal treatment [7, 8]. Such a complex 
treatment in combination with certain modes makes it possible to obtain strengthened surface diffuse layers of significant hardness and low brittleness, and to work well under severe operating conditions [9]. The use of several methods of technological impact on the treated surface allows you to select the optimal modes to ensure the advantages of the above methods.

In the literature $[10,11]$ there are combinations of several CTT methods, which can be performed both sequentially and simultaneously. Such an approach to the application of chemical treatment methods, as well as the type and modes of processing, makes it possible to obtain strengthened surface layers of the required characteristics.

Researchers who used hardening of machine parts and tools by methods of chemicalthermal treatment by saturating the surface layers with two or more components note such positive qualities that reinforcement objects acquire [8-11]. Most scientists point to the acquisition of the simultaneous properties of high hardness and plasticity, which is impossible with one-component diffusion saturation.

A particularly valuable (promising) CTT method is the joint diffuse saturation of the surface with chromium and titanium, which will make it possible to obtain reinforced layers of both high hardness and corrosion resistance. Research is being carried out [12] on the application of two-component coatings (chromium and titanium) and additionally by one-component (chromium) method of CTO. The authors, after examining samples coated with chromium and titanium carbides $\left(\mathrm{Cr}_{7} \mathrm{C}_{3}, \mathrm{Cr}_{23} \mathrm{C}_{6}, \mathrm{TiC}\right)$ with a total thickness of $12-18$ microns, came to the following conclusions. Coatings consisting of carbides of stoichiometric composition $\mathrm{Cr}_{7} \mathrm{C}_{3}$ have increased brittleness. Simultaneous diffuse saturation of steel surfaces with chromium and titanium is accompanied by the formation of titanium carbides in the coating next to chromium carbides, which provides a significant increase in the hardness of the carbide layer.

The purpose of this work is obtaining diffusion coatings from composite saturating powder media, to study the structure, phase, chemical composition and properties of the resulting protective coatings.

\section{Research materials and methods}

Chemical-thermal treatment was carried out on samples of technical iron, steels 20, 45, U8 in an open-type container in the operating temperature range $950-1200{ }^{\circ} \mathrm{C}$ isothermal holding time of 2-2.5 hours. Mixtures of powders of the following materials were used for the charge: chromium oxide $-\mathrm{Cr}_{2} \mathrm{O}_{3}$, oxide alumina - $\mathrm{Al}_{2} \mathrm{O}_{3}$, molybdenum oxide, ammonium chloride, iodine, dispersion of $60-120 \mu \mathrm{m}$.

Surface preparation of the samples included successive steps of grinding, polishing and degreasing in acetone. Initiation of the saturation process was performed by preheating in a furnace to the temperature of the beginning of spontaneous combustion (heating rate $-0,5^{\circ} \mathrm{C} / \mathrm{s}$ ). The temperature of the composite saturating charge was monitored by a chromel-alumel thermocouple in a protective cover inserted directly into the volume of the charge and connected to a potentiometer of the PCB series.

The study of the microstructure of structural materials with protective coatings was performed from transverse sections on a metallographic microscope model «Neophot-21» and «Neophot-32» at a magnification of $\times 150-\times 500$. Processing of cross sections was performed according to standard methods. A $4 \%$ solution of nitric acid $\mathrm{HNO}_{3}$ in ethyl alcohol was used to reveal the microstructure of coatings obtained on technical iron and steels.

The study of the thickness of the coatings was performed on cylindrical samples with a diameter of 10-15 mm. Determination of the thickness of the coating is carried out on the cross sections on the device PMT-3M or on a metallographic microscope «Neophot-32».

Micro-X-ray spectral analysis of protective coatings is performed on a universal, highperformance, auto-emission, scanning electron microscope Carl Zeis AG-SUPRA 40 WDS, which uses an electron-optical column GEMINI 3rd generation on cross sections.

Research results. When molybdenation using a composite saturating medium in the system №1, using molybdenum powder, a gas phase is formed containing compounds $\mathrm{H}_{1} \mathrm{H}_{2}, \mathrm{H}_{3}$, $\mathrm{Cl}, \mathrm{Cl}_{2}, \mathrm{Cl}_{3}, \mathrm{Cl}_{6}, \mathrm{I}, \mathrm{I}_{2}, \mathrm{I}_{3}$ with chemical elements. With increasing temperature, an increase in the amount of halides is observed.

This confirms the possibility of transferring alloying elements to form molybdenum diffuse coatings. Also, the amount of products in the gaseous phase increases and condensed products of system No. 1 are released. 
It is characteristic that in the temperature range of 700-1500 K, the decomposition of reaction products occurs during molybdenization, which is confirmed by the production of decomposition substances and a sharp increase in the number of moles of gas.

Gaseous products interact with elements of the powder system $(\mathrm{Al}, \mathrm{Mo}, \mathrm{Cr}$ ) and are transformed into the gas phase $\left(\mathrm{CrH}, \mathrm{CrOH}, \mathrm{CrCl}, \mathrm{CrCl}_{2}, \mathrm{CrCl}_{3}, \mathrm{CrOH}, \mathrm{CrOCl}_{2}, \mathrm{CrI}, \mathrm{CrI}_{2}, \mathrm{CrI}_{3}\right.$, $\left.\mathrm{MoCl}, \mathrm{MoCl}_{2}, \mathrm{MoCl}_{3}, \mathrm{MoCl}_{4}, \mathrm{MoOCl}, \mathrm{MoOCl}, \mathrm{MoI}, \mathrm{MoI}_{2}, \mathrm{MoI}_{3}, \mathrm{MoI}_{4}\right)$. At temperatures above $700 \mathrm{~K}$, the fraction of the condensed phase remains practically unchanged. This fact suggests that in the temperature range of 700-1700 K, reactions occur with the release of a condensed phase, but without changing the number of moles, which is typical for decomposition reactions, exchange with material, that is, in fact, chemical transport of elements occurs. In the temperature range $700-1700 \mathrm{~K}$ are: condensed compounds: $\mathrm{Al}_{2} \mathrm{O}_{3}(\mathrm{c}), \mathrm{AlN}(\mathrm{c}), \mathrm{Fe}(\mathrm{c}), \mathrm{Cr}(\mathrm{c}), \mathrm{CrCl}_{2}(\mathrm{c}), \mathrm{CrI}_{2}(\mathrm{c})$, $\mathrm{Mo}(\mathrm{c}), \mathrm{Cr}_{2} \mathrm{~N}(\mathrm{c})$.

The results of thermodynamic modeling in the ECD-Mo2O3-AlT system are shown in Figure 1.

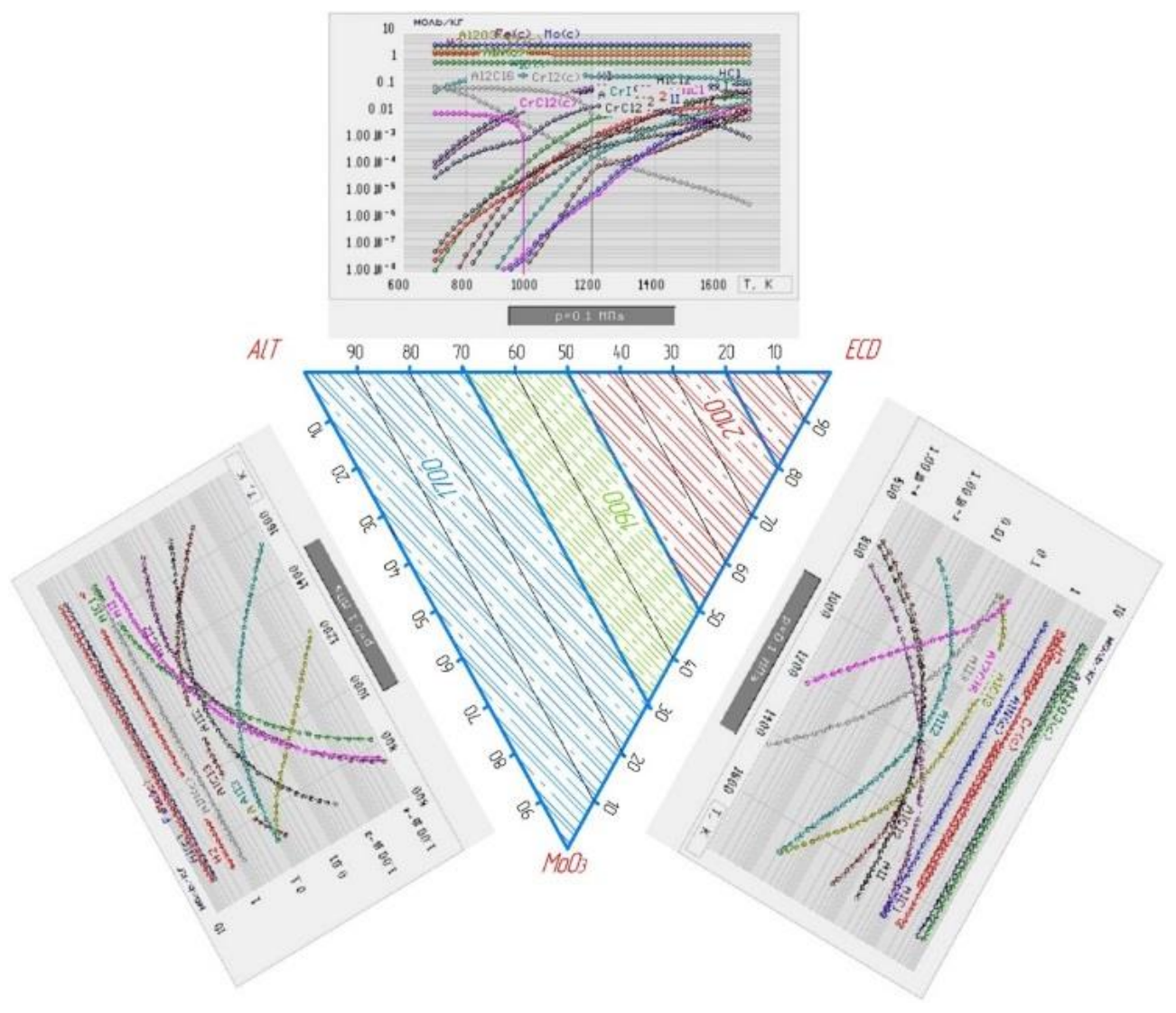

Fig. 1. Distribution of adiabatic temperature $\mathrm{T}_{\mathrm{ad}}, \mathrm{K}$, when carrying out the process in a compositional saturating medium № 2 for the ECD-MoO 3 -ALT system: 1 - gaseous medium for the ALT-ECD system, 2 - gaseous medium for the ALT - $\mathrm{MoO}_{3}$ system, 3 - gaseous medium for the $\mathrm{MoO}_{3}$ - ECD system.

When molybdenum is used with the use of a composite saturating medium of system № 2 , a gas phase is formed containing compounds $\mathrm{H}, \mathrm{H}_{2}, \mathrm{H}_{3}, \mathrm{Cl}, \mathrm{Cl}_{2}, \mathrm{Cl}_{3}, \mathrm{OH}, \mathrm{I}, \mathrm{I}_{2}, \mathrm{I}_{3}$ with chemical elements. With an increase in temperature, an increase in the amount of halides of system №2 . is observed. This confirms the possibility of transferring alloying elements to form molybdenum diffuse coatings. Also, the amount of products in the gaseous phase increases and condensed products are released.

Gaseous products interact with elements of the powder system (Al, Mo, Cr) and are transformed into the gas phase $\left(\mathrm{AlH}, \mathrm{AlH}_{2}, \mathrm{AlH}_{3}, \mathrm{AlCl}, \mathrm{AlCl}_{2}, \mathrm{AlHCl}, \mathrm{AlH}_{2} \mathrm{Cl}, \mathrm{AlHCl}, \mathrm{AlI}_{2} \mathrm{AlI}_{2}\right.$, $\left.\mathrm{AlI}_{3}, \mathrm{MoCl}_{3}, \mathrm{MoI}, \mathrm{MoI}_{2}, \mathrm{CrH}, \mathrm{CrOH}, \mathrm{CrCl}, \mathrm{CrCl}_{2}, \mathrm{CrCl}_{3}, \mathrm{CrI}, \mathrm{CrI}_{2}, \mathrm{CrI}_{3}, \mathrm{MoCl}_{3}, \mathrm{MoI}, \mathrm{MoI}_{2}\right)$. At temperatures above $700 \mathrm{~K}$, the fraction of the condensed phase remains practically unchanged. 
This fact suggests that in the temperature range of 500-1500 K, reactions occur with the release of a condensed phase, but without changing the number of moles, which is typical for decomposition reactions, exchange with material, that is, in fact, chemical transport of elements occurs. In the temperature range $700-1450 \mathrm{~K}$ there are condensed compounds: $\mathrm{Al}(\mathrm{c}), \mathrm{Al}_{2} \mathrm{O}_{3}(\mathrm{c})$, $\operatorname{AlN}(\mathrm{c}), \mathrm{Cr}(\mathrm{c}), \mathrm{Mo}(\mathrm{c})$.

According to thermodynamic modeling data, molybdenum is completely reduced from oxide, and its concentration distribution over the triangular region is an inclined plane. Chromium is also completely reduced by aluminum. The distribution of adiabatic temperature during the process in a composite saturating medium $\mathrm{T}_{\mathrm{ad}}$ for the $\mathrm{ECD}-\mathrm{MoO}_{3}$-ALT system is shown in Figure 1.

The maximum temperature corresponds to the ECD angle. Figure 1 shows the main halides of the gas phase. The highest temperature value $T_{a d}=T_{m}\left(\mathrm{Al}_{2} \mathrm{O}_{3}\right)=2327 \mathrm{~K}$

The preparation of molybdenum diffusion layers on structural materials was carried out in powder composite saturating media in two systems, which consisted of both pure molybdenum and its oxide. Using 3D-modeling of microstructures, it was possible to more fully establish the nature of the distribution of phases and inclusions in the diffusion layer (Fig. 2).

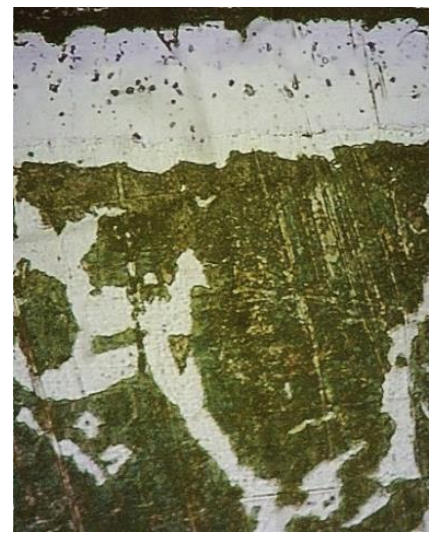

a



d



b

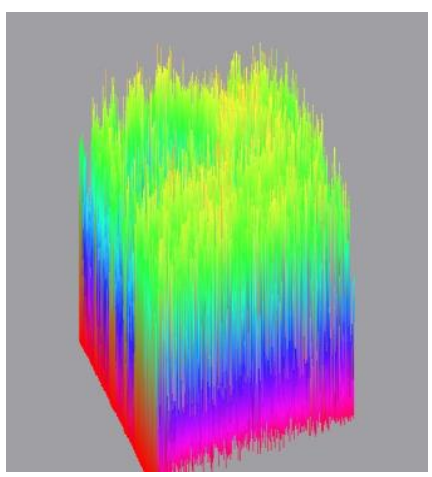

e

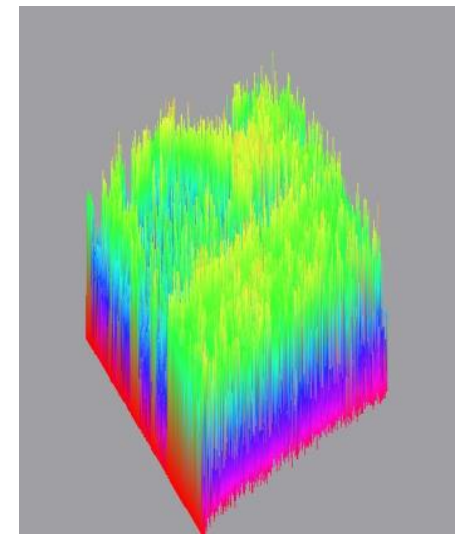

c



$\mathrm{f}$

Fig. 2. Study of the microstructure of the molybdenum diffusion layer:

a-molybdenum layer obtained in system № 2, x150, b- 2D image, c-voxelization of a $3 \mathrm{D}$ structure when assessing porosity, $d$ - setting threshold values to enhance the difference in phase composition, e- $3 \mathrm{D}$ structure for assessing carbide phases when identifying microstructures, $\mathrm{f}-3$

$\mathrm{D}$ depiction of the nature of the distribution of the main saturating elements.

The surface saturation of structural materials was carried out at temperatures of 1100$1200{ }^{\circ} \mathrm{C}$ for 2-2,5 hours. The chemical composition and structure of the diffusion layer are mainly determined by the ratio of the active atoms of the saturating elements $\mathrm{Mo}, \mathrm{Al}, \mathrm{Cr}$, and the gradient of the chemical potential. Upon saturation in composite saturating media in system №1, where molybdenum is in its pure form, a diffusion layer of molybdenum carbide Mo2C (molybdenum 93-95\%), is formed on the surface of steels 45 and U8, with inclusions of Fe7Mo6 , as well as complex carbide $\mathrm{Fe} 3 \mathrm{Mo} 3 \mathrm{C}$ и $\mathrm{Fe} 2 \mathrm{Mo} 2 \mathrm{C}$ (47- 49\% molybdenum) evenly distributed over the thickness of the carbide zone. 
Upon saturation in composite saturating media in system №2, diffuse layers are formed on the surface of structural materials, which contain $\mathrm{Mo}_{2} \mathrm{C}$ and $\alpha$ phases - the $\mathrm{Cr}, \mathrm{Al}$, Mo phase, the inclusion of $\mathrm{Fe}_{7} \mathrm{Mo}_{6},(\mathrm{Fe}, \mathrm{Cr}, \mathrm{Al}, \mathrm{Mo})_{23} \mathrm{C}_{6}$. Carbides of three types were found: hexagonal chromium carbide $\mathrm{Cr}_{7} \mathrm{C}_{3}$ and carbides $\mathrm{Mo}_{2} \mathrm{C}, \mathrm{Cr}_{23} \mathrm{C}, \mathrm{Fe}_{3} \mathrm{Mo}_{3} \mathrm{C}$ and $\mathrm{Fe}_{2} \mathrm{Mo}_{2} \mathrm{C}$.

Molybdenum diffusion layers obtained using composite saturating media on technical iron and steels are diffuse in nature and are characterized by uniformity in thickness (Fig. 2, b).

The test results of steel samples for wear under sliding friction on the friction machine SMT-1 are shown in Fig. 3.

At tests in the conditions of sliding friction the best wear resistance among the considered diffusion coverings have vanadium, titanium and borized. Their wear resistance is $1,8-2,3$ times greater than that of coatings obtained under isothermal conditions. This can be explained by the higher microhardness, which is for coatings obtained in isothermal conditions by vanadium $\mathrm{H}_{100}=$ 22000-23000 MPa during titanium doping $\mathrm{H}_{100}=16000-16500 \mathrm{MPa}$, during boron doping $\mathrm{H}_{100}$ $=15000-16000 \mathrm{MPa}$.



$1-\mathrm{W} ; 2-\mathrm{Mo} ; 3-\mathrm{Al} ; 4-\mathrm{B} ; 5-\mathrm{Ti} ; 6$ - V

Fig. 3. Wear resistance of protective coatings on steel 45 obtained composite saturating media of the second system (SMT-1 friction testing)

In the conditions of use of composite saturating charges microhardness reaches the following values: at vanadization $\mathrm{H}_{100}=23000-24000 \mathrm{M \Pi a}$, at titanization $\mathrm{H}_{100}=16500-17000$ МПа, при at boring $\mathrm{H}_{100}=16000-16500$ МПа. The obtained results correlate with the indicators of wear resistance.

\section{Conclusions:}

1. Received diffusion coatings from composite saturating powder media consisting of both pure metal powders and their oxides. The wear resistance of protective coatings was determined when tested on the machine rubbing SMT-1.

2. Thermodynamic modeling was carried out to establish the composition of the gas phase during molybdenization and the distribution of the adiabatic temperature $T_{a d}, K$, was investigated when the process was carried out in a composite saturating charge.

3. The microstructures of the molybdenum diffusion layer were investigated using $2 \mathrm{D}$ and 3D images when assessing porosity, assessing carbide phases when identifying microstructures and the nature of the distribution of the main saturating elements.

4. The phase composition of molybdenum layers at saturation in system № 1, which was established, which on steels 45 and U8 consists of a layer of molybdenum carbide $\mathrm{Mo}_{2} \mathrm{C}$ (molybdenum $93-95 \%$ ), with inclusions $\mathrm{Fe}_{7} \mathrm{Mo}_{6}$, as well as carbide of complex composition $\mathrm{Fe}_{3} \mathrm{Mo}_{3} \mathrm{C}$ and $\mathrm{Fe}_{2} \mathrm{Mo}_{2} \mathrm{C}$ (47- 49\% molybdenum) uniformly distributed over the thickness of the carbide zone. Upon saturation in composite saturating media in system №2, diffuse layers are formed on the surface of structural materials, which contain $\mathrm{Mo}_{2} \mathrm{C}$ and $\alpha$ - phases - $\mathrm{Cr}, \mathrm{Al}, \mathrm{Mo}$, the inclusion of $\mathrm{Fe}_{7} \mathrm{Mo}_{6},(\mathrm{Fe}, \mathrm{Cr}, \mathrm{Al}, \mathrm{Mo})_{23} \mathrm{C}_{6}$. Carbides of three types were found: hexagonal chromium carbide $\mathrm{Cr}_{7} \mathrm{C}_{3}$ and carbide $\mathrm{Mo}_{2} \mathrm{C}, \mathrm{Cr}_{23} \mathrm{C}, \mathrm{Fe}_{3} \mathrm{Mo}_{3} \mathrm{C}$ and $\mathrm{Fe}_{2} \mathrm{Mo}_{2} \mathrm{C}$. 


\section{References}

1. Medyukh R.M., Medyukh V.K., Dovbush T.A. Diffusion drilling of plasma coatings based on molybdenum. Bulletin of the Ukrainian Materials Society named after I.M. Frantsevich, Kyiv: IPM named after IM Frantsevich NAS of Ukraine, 2019. №12. C.83- 92

2. Medyukh R.M., Medyukh V.K., Uvarova I.V. Diffusion chromium plating of plasma coatings based on molybdenum. Powder metallurgy. Kyiv: IPM named after IM Frantsevich NAS of Ukraine, 2017. №09 / 10. C.63-69

3. Trefilova N.V. Analysis of modern methods of applying protective coatings. Modern high technologies. 2014. No. 10. P. 67-67.

4. Dombrovsky Yu. M., Stepanov M.S. New aspects of chemical-thermal processing of metals in powder media. Bulletin of DSTU. 2011. T. 11, No. 8 (59), Issue. 1.P. 1217-1221.

5. Lakhtin Yu. M., Arzamasov BN Chemical-thermal treatment of metals. M.: Metallurgy, $1985.255 \mathrm{~s}$.

6. Borisenok G.V., Vasiliev L.A., Voroshnin L.G. Khimiko-thermal treatment of metals and alloys: a reference book. M.: Metallurgy, 1981.424 p.

7. Voroshnin L.G., Mendeleeva O.L., Smyotkin V.A. Theory and technology of chemical-thermal processing. New knowledge, $2010.297 \mathrm{p}$.

8. Belkin PN Electrochemical-thermal treatment of metals and alloys. M.: Mir, 2005.336

p.

9. Lygdenov BD, Guryev AM, Mosorov VI, Butukhanov VA Perspective diffusion coatings. International Journal of Experimental Education. 2015. No. 12-4. S. 573-573.

10. Stetsko A. Zmitsnennya machine parts by a complex method. 2015 pp. 125-130. [Electronic resource]: Access mode: http://www.ctp.uad.lviv.ua/images//ktd/33_stecko.pdf

11. Loburak V. Ya., Lukyanyuk MV Improving the performance characteristics of deposited coatings on steel $12 \mathrm{X} 18 \mathrm{H} 10 \mathrm{~T}$ by method 130 of thermal diffusion treatment. Problems of Tribology (ProblemsofTribology) 2012, № 3. P. 48-51.

12.Loskutova T.V., Khyzhnyak V.G., Pogrebova I.S., Bobina M.M., Degula A.I. Heat resistance of carbide coatings obtained by sequential saturation of steel U8A with chromium and titanium. Scientific news of NTTU "KPI", 2009. №6. P.93-97.

Середа Б.П., д.Т.н., проф., Кругляк И.В., к.т.н., доц.

Днепровский государственный технический университет

\section{ПОВЕРХНОСТНОЕ УПРОЧНЕНИЕ КОНСТРУКЦИОННЫХ МАТЕРИАЛОВ С ИСПОЛЬЗОВАНИЕМ КОМПОЗИЦИОННЫХ НАСЫЩАЮЩИХ СРЕД}

В статье рассмотрено формирование структуры защчитных диффузионных слоев с использованием композиционных насыщщающих сред на конструкционных материалах $c$ различным содержанием углерода. Проведен термодинамический анализ газовой фазы при насыщении. Определен состав газовой фазы газообразных продуктов, взаимодействующих с элементами порошковой системы $(\mathrm{Al}, \mathrm{Mo}, \mathrm{Cr})$ и образуюшие газовую фазу (появляются $\mathrm{CrH}$, $\mathrm{CrOH}, \mathrm{CrCl}, \mathrm{CrCl}_{2}, \mathrm{CrCl}_{3}, \mathrm{CrOH}, \mathrm{CrOCl}, \mathrm{CrI}, \mathrm{CrI}_{2}, \mathrm{CrI}_{3}, \mathrm{MoCl}, \mathrm{MoCl}_{2}, \mathrm{MoCl}_{3}, \mathrm{MoCl}_{4}, \mathrm{MoOCl}$, $\mathrm{MoOCl}_{2}, \mathrm{MoI}, \mathrm{MoI}_{2}, \mathrm{MoI}_{3}, \mathrm{MoI}_{4}$ ). С использованием 3D-моделирования микроструктур удалось полно установить характер распределения фаз и включений в диффузионном слое. Связь $3 D$ микроструктуры материала и его физико-механических и эксплуатаиионных свойств конструкиионных материалов позволили провести моделирование по получению оптимального состава разработанных насыщающих композищионных шихты. $\mathrm{Ha}$ поверхности конструкиионных материалов формируются диффузные слои, имеющие в своем составе фазы $\mathrm{Mo}_{2} \mathrm{C}$ и а - фаза $\mathrm{Cr}$, Al, Mo, с включениями $\mathrm{Fe}_{7} \mathrm{Mo}_{6}$, $(\mathrm{Fe}, \mathrm{Cr}, \mathrm{Al}, \mathrm{Mo})_{23} \mathrm{C}_{6}$. Былли обнаружень карбиды трех типов: гексагональный карбид хрома $\mathrm{Cr}_{7} \mathrm{C}_{3}$ и карбиды $\mathrm{Mo}_{2} \mathrm{C}, \mathrm{Cr}_{23} \mathrm{C}, \mathrm{Fe}_{3} \mathrm{Mo}_{3} \mathrm{C} u$ $\mathrm{Fe}_{2} \mathrm{Mo}_{2} \mathrm{C}$. Исследовано физико-механические и експлуатационные свойства конструкциионных материалов с защитными диффузмонными покрытиями. При испытаниях в условиях трения скольжения лучшую износостойкость среди рассмотренных диффузионных покрытий имеют ванадиевые, титановые и борированные. Их износостойкость в 1,8 - 2,3 раза больше, чем у покрытий, полученных при стационарных изотермических условиях. 
Keywords: диффузия, моделирование, молибден, микроструктура, фаза, микротвердость, остаточные напряжения, износостойкость.

Середа Б.П., д.т.н., проф., Кругляк І.В., к.т.н., доцент

Дніпровський державний технічний університет

\section{ПОВЕРХНЕВЕ ЗМІЦНЕННЯ КОНСТРУКЦІЙНИХ МАТЕРІАЛІВ 3 ВИКОРИСТАННЯМ КОМПОЗИЦЙНИХ НАСИЧУЮЧИХ СЕРЕДОВИЩ}

У статті розглянуто формування структури захисних дифузійних шарів $з$ використанням композиційних насичуючих середовищ на конструкиійних матеріалах з різним вмістом вуглеию. Проведено термодинамічний аналіз газової фази при насиченні. Визначено склад газової фази Газоподібні продукти, взаємодіють з елементами порошкової системи (Al, $\mathrm{Mo}, \mathrm{Cr}$ ) і переводяться в газову фазу (з'являються $\mathrm{CrH}, \mathrm{CrOH}, \mathrm{CrCl}, \mathrm{CrCl}, \mathrm{CrCl}, \mathrm{CrOH}$, $\mathrm{CrOCl}_{2}, \mathrm{CrI}, \mathrm{CrI}_{2}, \mathrm{CrI}_{3}, \mathrm{MoCl}, \mathrm{MoCl}_{2}, \mathrm{MoCl}_{3}, \mathrm{MoCl}_{4}, \mathrm{MoOCl}, \mathrm{MoOCl}_{2}, \mathrm{MoI}_{1} \mathrm{MoI}_{2}, \mathrm{MoI}_{3}, \mathrm{MoI}_{4}$ ). 3 використанням 3D-моделювання мікроструктур вдалося більш повно встановити характер розподілу фаз $i$ включень в дифузійному шарі. Зв'язок 3D-мікроструктури матеріалу $і$ його фізико-механічних властивостей дозволили провести моделювання 3 отриманням оптимального складу розроблених композиційних иихти для насичення. На поверхні конструкційних матеріалів формуються дифузні шари, що мають в своєму складі фази $\mathrm{Mo}_{2} \mathrm{C} i$ $\alpha$ - фаза $\mathrm{Cr}, \mathrm{Al}, \mathrm{Mo}$, включення $\mathrm{Fe}_{7} \mathrm{Mo}_{6},(\mathrm{Fe}, \mathrm{Cr}, \mathrm{Al}, \mathrm{Mo})_{23} \mathrm{C}_{6}$. Були виявлені карбіди трьох типів: гексагональний карбід хрому $\mathrm{Cr}_{7} \mathrm{C}_{3} i$ карбіди $\mathrm{Mo}_{2} \mathrm{C}, \mathrm{Cr}_{23} \mathrm{C}, \mathrm{Fe}_{3} \mathrm{Mo}_{3} \mathrm{C}$ и $\mathrm{Fe}_{2} \mathrm{Mo}_{2} \mathrm{C}$. Досліджено фізико-механічні та експлуатащійні властивості конструкційних матеріалів із захисними дифузійними покриттями. При випробуваннях в умовах тертя ковзання найкращу зносостійкість серед розглянутих дифузійних покриттів мають ванадієві, титанові $i$ борорувані. Їх зносостійкість в 1,8 - 2,3 рази більме, чим у покриттів, отриманих при ізотермічних умовах.

Keywords: дифузія, моделювання, молібден,мікроструктура, фаза, мікротвердість, залишкові напруги, зносостійкість. 